\title{
Negotiation of Meaning and Modified Output Elicitation across Two Tasks
}

\author{
Mehdi Rahimian ${ }^{1,2}$ \\ ${ }^{1}$ University of Isfahan, Iran \\ ${ }^{2}$ University of Manitoba, Canada \\ Correspondence: Mehdi Rahimian, University of Manitoba, Canada. E-mail: rahimiam@cc.umanitoba.ca
}

\author{
Received: August 26, 2013 Accepted: September 17, 2013 Online Published: November 5, 2013 \\ doi:10.5539/elt.v6n12p114 URL: http://dx.doi.org/10.5539/elt.v6n12p114
}

\begin{abstract}
Analysing the effects of second language (L2) production on L2 learners' interlanguage (IL) modifications is the main scope of this paper. For this purpose, English L2 learners' output production and IL modifications in performing two different task types, one-way and two-way tasks, are compared. The one-way task used in this study was a story narration task and the two-way task was a communication task. Eighteen intermediate-level English L2 learners participated in the research. Findings indicate that the L2 learner participants modified their output during negotiation of meaning in both one-way and two-way tasks on a self-triggered manner. The participants also modified their output during negotiation of meaning in the two-way task based on an other-triggered manner. There was not enough evidence in the results supporting other-triggered modified output (MO) elicitation in the one-way task. The results also indicate that in both tasks, the participants modified their IL structures more as a result of self-triggered, or self-initiated, activation than other-triggered, or other-initiated, activation. It can be concluded that in meaning negotiation, both in the one-way and two-way tasks, the English as a foreign language (EFL) learners tended to modify their IL without interlocutor's request for clarification, and in the two-way task they also modified their output responding to interlocutor's appeal for clarification. Making reference to the literature, it is argued that the output effect and its subsequent potential modifications might be an L2 learner's attempt to automatize, or gain mastery over, the already learnt L2 forms. Accordingly, the observed MOs, or at least some of them, might be attributable to the learner's attempts in choosing between first language (L1) and L2 forms.
\end{abstract}

Keywords: second language acquisition, negotiation of meaning, modified output, uptake, output, language related episode, one-way task, two-way task

\section{Introduction}

Krashen's ideas on second language acquisition (SLA) published in the 1980s, have caused a tendency for their verification and application. One of these ideas, the comprehensible input hypothesis, as a tentative applicable idea for L2 classrooms has caused some controversies. Some researchers have reported on the insufficiency of comprehensible input for L2 instruction, resulting in the L2 learners' high proficiency development just in L2 comprehension and not in L2 production (Swain, 1985). Swain (1985), considering the case of immersion students, conferred that comprehensible input is not enough in acquiring an L2, and chances of L2 production, or comprehensible output, would serve as L2 development facilitative device in L2 acquisition (also Foster, 1998; Izumi, Bigelow, Fujiwara \& Fearnow, 1999; Izumi, 2003; Shehadeh, 1999, 2001, 2002; Swain, 1995, 2000; Van den Branden, 1997).

The argument that comprehensible input is not enough for successful L2 acquisition/learning led some researchers in the field to argue in favour of a joint focus-on-meaning and focus-on-form instruction (for example, Long, 1996). Some researchers have argued that L2 learners develop grammatical accuracy in their L2 through 'negotiation of meaning' (Gass, 1997; Pica, 1994). Long (1996) proposed that the best way to help L2 learners focus on form is to engage them in negotiation of meaning. According to Swain (1985), when an L2 learner produces L2, especially when he/she experiences difficulty in communicating his/her meaning in the L2, he/she is pushed to modify his/her output, and as a result the output may become more target-like. This type of focus-on-form has been called incidental focus-on-form (Long, 1991). 
However, the potential effects of producing L2 during negotiation of meaning on L2 acquisition/learning in foreign language (FL) learning situations have not been explored enough, and the main focus of research has been on the interactions between native-nonnative speakers. Hence, nonnative-nonnative interaction is one of the sources of output production that has to be addressed in L2 research.

Some clarifications on terminology ambiguities may be helpful for the readers. The term comprehensible output as it was first used by Swain (1985) may cause some confusion. One might argue that if an L2 learner's output is comprehensible, it is less likely to need modifications. This point, noted by Van den Branden (1997), is resolvable using the term 'negotiated output', 'pushed output' or just 'output' respectively. However, some researchers in the field might want to use the more conventional term comprehensible output, while others tend to use the term output and the output hypothesis (For example, Izumi, 2003; Shehadeh, 2002). In this paper, mainly, the terms output is used referring to the produced language by the L2 learners. It has to be noted that the term uptake has been used more recently to account for the modified speech as the result of interaction (for example Aftiska, 2012). One of the differences between output and uptake might be in that uptake may refer to what is retained in the mind of the learner after a language related episode (LRE) has happened. Another terminological difference, as used in this paper, is the use of self-triggered and other-triggered. The reason for using these terms is that the observed phenomena in LREs and MOs might be attributable to something other than reflection on the output. As it is discussed in this paper, the output and MO might be (partially) attributable to the L1-L2 form competitions in the mind of an L2 learner. Thus using the above mentioned terms seems more appropriate.

Regarding MO production in L2, there are two possible sources for modification in interactions among L2 learners and also in interactions among L2 learners and native speakers: self and other. Self-triggered MO is the kind of output that the producer produces to clarify the meaning in a self-activation manner. Other-triggered MO, on the other hand, is the kind of modified output that the L2 learner produces to clarify his/her meaning to his/her interlocutor(s) on his/her interlocutor's request/signal for clarification (Shehadeh, 1999, 2001. The terms used in Shehadeh are self-initiated, other-initiated, self-initiation, and other-initiation). In this paper, the terms self-triggered and other-triggered are used to avoid any potential conceptual problems.

To test the potential effects of producing output in EFL learning situations, two task types were used: one-way and two-way tasks. The data analyses were done based on LREs. An LRE is the L2 learner's reaction to his/her L2, i.e. noticing his/her production and (possibly) trying to modify it (Swain and Lapkin, 1995). The main research question in the experiment was whether or not negotiation of meaning in L2 will lead to modified output production. The possible sources of MO, self or other, were also investigated.

\section{Literature Review}

An important and influential theory in SLA research is the Monitor Model. As the base ground for the comprehensible input, the monitor model assumes five hypotheses for language learning. One of these hypotheses is input hypothesis. Krashen (1985) stated that language rules are acquired in a predictable order. To explain this predictability, Krashen (1985) argues that language is acquired through comprehensible input. Krashen (1985) also stated that an L2 learner moves from i, that is his/her current level in the L2, to $\mathrm{i}+1$, that is the next level along the natural order by understanding input containing $i+1$. As put forward by McLaughlin (1987) there are two other hypotheses about the input hypothesis: one that speaking is the "result of language acquisition not its cause" and the other that through input "the necessary grammar is automatically provided" (McLaughlin, 1987, p. 36).

Relying on these assumptions, the language teacher does not need to attempt deliberately to teach the next structure along the natural order. The next structure has to be provided in the right way, and automatically will be acquired if the L2 learner receives a sufficient amount of comprehensible input (Krashen, 1985). However, one of the objections made to Krashen's input hypothesis is Swain's (1985) comprehensible output hypothesis. By examining the second language of the students enrolled in some immersion programs in Canada, Swain (1985) concluded that comprehensible input is not enough for successful L2 acquisition. Swain and Lapkin (1995) hypothesized that output is one of the incentives for noticing. In other words, the activity of producing the target language (TL) may prompt second language learners to consciously recognize some of their linguistic problems. This noticing the problem may bring something to the attention of the L2 learners that they need to discover about the L2.

Additionally, it has been argued that an L2 learner's modification of his/her L2 during production would contribute to his/her internalization of the new forms (Pica, Holliday, Lewis, \& Morgenthaler, 1989). Another benefit of output could be testing the L2 learner's hypotheses about L2. The L2 learners may 'experiment with 
new structures and forms, and expand and exploit their interlanguage resources in creative ways' (Pica et al, 1989, p. 64).

Swain $(1993,1995)$ has identified three functions of output in second language acquisition: hypothesis testing function, metalinguistic function, and noticing/triggering function. Another more comprehensible classification of the possible functions associated with L2 output summarizes four functions for output in SLA: "(a) metalinguistic talk; (b) noticing of and focusing learners' attention on subsequent input; (c) hypothesis testing; and (d) syntactic processing" ( Shehadeh, 2002, p. 624). Moreover, research studies suggest that there is IL retention of the produced solutions to linguistic problems achieved through metalinguistic talk (Kowal and Swain, 1994, 1997; Swain 1998, 2000). Swain (1998) argues that LRE may be a source of language learning. In another study, Shekary (2004) studied the role of negotiation of meaning and noticing in SLA development on cyber space. She found that noticing did occur in online negotiations. However, these occasions of noticing were different from offline settings and from task to task. Shekary (2004) found that among the three tasks she used for her study, the dictogloss tasks generated the most LREs and jigsaw tasks generated the least LREs, while 'free discussion' tasks came in between. Izumi and Bigelow (2000), and Izumi et al. (1999) explored the effects of output on the learners' subsequent noticing of and focusing on subsequent input. They found that there may be a significant improvement on the learners' IL if the learners have opportunities of producing output. Additionally, Izumi (2002) suggests that output promotes noticing and results in a better L2 learning than input enhancement.

However, in producing output, a condition for the L2 learner may be created that he/she can make a cognitive comparison between his/her interlanguage (IL) form and the appropriate target language form. This helps the learner to expunge the non-target-like forms from his/her IL and acquire the appropriate target-like form. Izumi (2002) suggests that input enhancement is not sufficient to induce noticing of the mismatches between IL and TL, while output can promote both the processes of noticing the form in L2 and noticing the mismatches between IL and L2.

Ellis (1994) argues that the hypotheses about L2 formed by the L2 learners are tested through reading and listening and also through speaking and writing. He mentions that listening and reading provide more input. The new input helps the L2 learner modify, confirm, or reject his/her hypotheses about the TL forms. Still, some other hypotheses are tested productively. Swain $(1995,1997)$ states that production includes a series of learner generated hypotheses and assumptions about the L2 he/she is learning. When an L2 learner produces an off-target utterance or incomprehensible output, it may generate external feedback, usually realized through clarification request or explicit correction by the interlocutor. On some occasions, for example explicit corrections or clarification requests by the interlocutor, external feedback may enable the learner to replace the incorrect hypotheses about the L2 rules with the correct ones (Lyster, 1998; White, 1991). White (1991) argued that negative evidence received by the L2 learner may help them acquire the appropriate TL forms by triggering his/her mental processes. In other cases, for example in clarification requests, external feedback may force the learner to modify his/her IL and thus make it more comprehensible or more target-like. Similarly, clarification requests, on occasions, may force the L2 learner to modify his/her IL performance. The result will be a more modified output produced by the L2 learner (Swain, 1998; Swain and Lapkin, 1995).

Shehadeh (1999) examines the effects of output and hypothesis testing on internalizing linguistic knowledge, suggests that an L2 learner tests his/her internally generated hypotheses about the L2. Shehadeh (1999, 2002) states that the lack of partner's feedback, i.e. an external feedback, may be regarded by the L2 learner as a confirmation signal for his/her hypotheses. Another report related to the effects of comprehensible output on L2 development, showed that both self and other-initiations provided nonnative speakers with good opportunities of producing modified output (Shehadeh, 2001). Based on the comprehensible output hypothesis, speaking or writing in an L2 enables the L2 learner to move from the open-ended semantic analysis of the target language to a more syntactic analysis of the L2 (Swain, 1985). Swain (1985) argued that syntactic processing mainly has to do with the relationship between words. Syntactic processing operates mainly at the phrasal, clausal, and sentential levels. Kowal and Swain (1997) mention that in syntactic processing, the learners 'move beyond processing words as independently functioning lexemes and come to consider them in their relationship to other words in the sentences' (p. 287). As mentioned by Swain (1991), after focusing on comprehensible input for more than eight years, the immersion students' productive skills, namely speaking and writing, "remain far from native-like" (p. 98). Kowal and Swain (1997) have attempted to justify the L2 learners' movement from semantic processing to syntactic processing via collaborative dialogue. Although Kowal and Swain (1997) attempted to show that output helps L2 learners go through syntactic processing, their findings are not so promising with respects to the long-term effects of output on syntactic processing in SLA. Still, another idea is that output has facilitative effects on syntactic processing in L2 (Izumi, 2002). 


\subsection{Psycholinguistic Rationale for the Output Hypothesis}

Levelt's (1989) speech production model has been used by a number of scholars to explain L2 acquisition (for example Bygate, 2001; de Bot, 1992; de Bot, Paribakht, \& Wesche, 1997; Izumi, 2003). Levelt's model was proposed addressing speech production by mature and monolingual native speakers of a language (for discussions one may refer to Nickels and Howard, 2000; Towell and Hawkins, 1994; Bock and Griffin, 2000). In Levelt's model, two types of knowledge, procedural and declarative, have been specified. The procedural knowledge is a kind of automatized knowledge that has to do with long-term memory and does not need the attention of the subject (Towell and Hawkins, 1994). In Levelts' model, procedural knowledge is the type of knowledge concerned about the quality of something happening, and it is fully automatized. Since the short-term memory is limited in capacity, processing in this memory is also limited (Shiffrin \& Scheider, 1977). In this model, the procedural knowledge is activated and is called into the short-term memory. Since this kind of knowledge, that is procedural knowledge, is fully automatized, it does not cost any demand on the short-term memory. Mature native speakers, according to Levelt, use their executive control, which is controlled knowledge, to construct the message that they are intending to produce. In his model, there is also declarative knowledge that includes: encyclopaedic knowledge, that is information about the world, situation knowledge, that is information about the specific nature of a situation, discourse model, that is information about the style of speech appropriate for a particular set of circumstances, and the lexicon as the dictionary type knowledge of words in the language. According to Levelt (1989), the language speaker generates a message by using declarative knowledge and combines this knowledge with procedural knowledge in the conceptualizer. The result is a preverbal message. The preverbal message expresses the meaning to be conveyed in propositional form. The result is activation of the appropriate lemma and its presence in the short-term memory. The lemma brings with it all the above-mentioned information, that is information about the meanings and syntactic information about the lexical items. Afterwards, the formulator automatically processes the message and gives it a surface syntactic form. In doing so, the formulator calls up all the other forms to meet the requirements of the initial forms. At this stage, that is surface stage, it is necessary to provide the exact information about the form required for phonological encoding. Additionally, to make sure that the message is delivered in the right order, there are some buffer areas between different unites. These buffer areas can delay the delivery of the message until the correct order is achieved.

There are disagreements on the role of output on SLA. For example de Bot $(1992,1996)$ suggests that it is possible for new knowledge to be generated in the production. This happens when the learner forms new words through the application of existing rules or the combination of previously acquired morphemes. Another function of output that de Bot $(1992,1996)$ regards more important, thus playing the main role, is strengthening the already existing L2 knowledge. In the case of the second role of output, Swain and Lapkin (1995) and Izumi (2003) agree with de Bot, although Izumi (2003) seems to accept just this role of the output in SLA. He argues that production processing is not language learning. However, as suggested by Nobuyoshi and Ellis (1993), it is useful to distinguish two meanings of acquisition: "(1) acquisition as the internalization of new forms and (2) acquisition as the increase in control over forms that have already been internalized" (p. 210). In Levelt's model, grammatical encoding in adult native speakers' production is assumed to be subconscious and automatic. It is possible that the grammatical encoding processes during production sensitize the L2 possibilities, and limit the learner's capabilities on L2 production. This sensitization can be reinforced through the feedback available for monitoring. It is argued that suggested areas for speech monitoring in Levelt's model make justification for grammatical consciousness rising by the language learners under certain circumstances (Dörnyei \& Kormos, 1998; Kormos 1999, 2000; Izumi, 2003).

In the case of L1 acquisition, Clark (1982) found that children monitor their own speech actively and try to repair their utterances. Clark (1982) suggested that monitoring and detecting mismatches between what they understand and what they can produce may function as part of the language learning by children. These findings signify the importance of output in language acquisition in general. However, regarding the case of L2 acquisition, de Bot $(1992,1996)$ considering Levelt's production model and Anderson's information-processing approach to skills acquisition (1982), suggested that output may not have direct contribution to new declarative knowledge, but will help in transferring declarative knowledge to procedural (1992).

\subsection{Short-Term Memory, Lexicon, and Language Processing}

Generally speaking, the short-term memory refers to the memory capacity that can store a limited amount of information for a short period of time (Baddeley, 2002). The term working memory was first introduced by Miller, Galanter, and Pribram in 1960. It has to be noted that the two terms, short-term memory and working memory, may refer to the same thing in some human studies (for a discussion, the interested reader may refer to 
Baddeley, 2002). According to Towell and Hawkins (1994) "the short-term memory store consists of a set of nodes which are activated in memory at the same time". And also "it is largely predetermined in its capacity" (pp. 162-163). For language learning, it has been argued that learning is the process of transferring patterns of activation from the short-term memory to the long-term memory store in such a way that new associations are formed within the already existing information structure in the mind of the learner (Towell and Hawkins, 1994). The process governing the operations of learning, are either controlled or automatic. The processing that requires the person's attention to the process in action is called controlled processing, and the processing that is carried out without that attention is automatic processing. So it can be mentioned that in L2 acquisition, those learners that have not automatized some parts of their L2 knowledge, may have more limitations on their achievements due to the limited nature of short-term memory and the fact that the L2 learners that have not automatized some of their L2 knowledge have to use controlled processing in comprehension and production. Moreover, the learners who have more abilities in automatizing their L2 knowledge possibly have more L2 acquisition potentiality (Towell and Hawkins, 1994). In comprehension, a learner who has not automatized some parts of his/her L2 knowledge has to use all the capacity of his/her short-term memory to extract the meaning from the input he/she receives. This learner, due to the limitations of the short-term memory, cannot pay (enough) attention to the language form he/she is receiving (Towell and Hawkins, 1994). In other words, the L2 learner receiving the L2 data can notice the information about the form in the incoming data when he/she can use 'a series of cost-free automatic processes' to extract the meaning (Towell and Hawkins, 1994, p. 164). These kinds of evidence can be used to question the efficiency of the input hypothesis. In other words, if an L2 learner wishes to notice the form in the L2 input they are receiving, they have to have automatized some parts of their knowledge in the L2. If they receive ' $\mathrm{i}+1$ ' input, then they may be able to understand what they are receiving, but cannot notice the new forms in it and thus may not be able to appropriately learn the new L2 form(s).

\subsection{Lexical Selection in Language Production}

It has been suggested that the formed messages in the first stage of language production have two main characteristics: a) they are not verbal or word formed, and b) they may be the same in nature, regardless of the language they are going to be uttered in (Bock and Griffin, 2000). Also, the messages stand somewhere between thought and language (Bock and Griffin, 2000). In the next stage, lexical selection is carried out that is finding a lexical entry, i.e. a lemma, which can adequately convey some parts of the message that is going to be uttered. The next step is retrieving the appropriate phonological form of the lemma, technically speaking its lexeme (Bock and Griffin, 2000). Monsell (1987) regarded separate, but linked, lexicons for input and output and separate, but linked, processors for phonological features in recognition and production. The link between these two processes serves as shared representation of the syntactic and semantic characteristics of lemmas (Monsell, 1987). Bock and Griffin (2000) conclude that certain key effects "emerge from recognition and production tasks that depend on access to a word's semantic and syntactic properties" and also different effects "emerge when tasks can be accomplished without tapping information about the meaning or structural privileges of a specific word" (p. 36). Additionally, they mention semantic processes are shared between the two systems of comprehension and production while phonological processes are divided in the two systems (Bock and Griffin, 2000). These are just some of the findings in different fields that can acknowledge our understanding of the ongoing processes in L2 acquisition. The time has come to have more multidisciplinary approaches to the field of language acquisition since it is through a multidisciplinary perspective that different aspects of a phenomenon are revealed.

\section{Methodology}

In the present research, the mini-dialogues or LREs produced by $18 \mathrm{EFL}$ learners performing two tasks and in twelve dyads were analysed. Each task had 18 participants teamed in groups of three, thus forming 12 dyads. In this study, the main motivating intent was to investigate the possible effect(s) of L2 production in interactions among EFL learners in negotiation of meaning, and also to analyse how such negotiations are potentially effective on MO production. These were measured while the participants performed the two tasks including a one-way task and a two-way task.

\subsection{Participants}

For the purpose of this study, 18 EFL learners including twelve females and six males were used as the research participants. These EFL learners were enrolled in a class in Academic Centre for Education, Culture, and Research (ACECR); at Isfahan University branch. The learners of ACECR are mainly university students or graduates. The learners are assigned to different class levels in this institute based on their performance on a placement test administered prior to their attendance. The EFL learners used in this study all had at least one year 
of continuous English learning. The placement test for these EFL learners had two sections, a written test and an oral interview. Considering the validity of the placement tests, a group of experienced EFL teachers in ACECR had made them and had tested them against standard tests before institutional implementation. However, to double check the proficiency level of the EFL learners, a placement test was also administered by the researcher.

\subsection{Materials}

The participants were asked to perform two tasks: a one-way and a two-way task. The first task was a story narration task, and the participants were asked to perform the task in groups of three. In this task each participant narrated a story that had been given to read individually. The stories were taken from Steps to understanding Series by Hill (1980). In the second task, to ensure a communicative environment leading to more data elicitation, they were asked to compile parts of an imaginary country named State of Freedonia, which was adapted from Shehadeh 2001. Each story narration session lasted about 20 to 30 minutes. About five minutes of the time was spent explaining the task by the researcher. After the researcher's explaining the task, the EFL learners read their stories individually and asked their questions from the researcher individually, if they had any. This was followed by each participant narrating his/her story, followed by other participants' potential questions. In the communication task, it took about ten minutes for the researcher to explain and read the task material and explain them. This was followed by the EFL learners completing the task in about 15 to 17 minutes cooperatively. All the conversations were recorded and later analysed for LREs. The reason for the selection of the story narration task was to provide the EFL learners with a task which is a one-way task. One-way task is a task that "involves one person explaining something to the rest of the class", or group (Brown, 2006: p. 9). In the story narration task, the flow of information is from the narrator to the interlocutors and the interlocutors are welcomed, but not forced, to participate in the task. Contrary to one-way tasks, "two-way speaking tasks, sometimes called jigsaw tasks, require students to share some information with others" (Brown, 2006, p. 9).

\subsection{Coding Procedure and Classification of the Data}

Coding of the data was done based on Swain and Lapkin (1995), based on the occurrence of LREs in the L2 learners' productions. There are also other ways of coding such data (for example Cumming, 1990; and Shehadeh, 1999). Since the main concern of the present study was to investigate the occurrence of LREs in the EFL learners' L2 production and the resulted modified outputs, the way Swain and Lapkin (1995) used in coding their data is an applicable and justifiable way for coding the data in the present research.

\section{Results}

The whole number of the LREs in the two tasks was 209. Out of 209 LREs, 158 belonged to the two-way task, and 51 LREs occurred in the story narration task. In the case of one way task, there were 46 cases of self-triggered LREs and five cases of other-triggered LREs.

Table 1. Frequencies of the LREs in the two tasks

\begin{tabular}{llll}
\hline & Self-triggered LREs & Other-triggered LERs & Total \\
\hline One-way task & 46 & 5 & 51 \\
Two-way task & 133 & 25 & 158 \\
Both tasks & 179 & 30 & 209 \\
\hline
\end{tabular}

Frequencies of the LREs in the two tasks have been summarized in Table 1. In each of these tasks there were six dyads in action, and each dyad included three EFL learners. 
Table 2. LREs in the one-way task in each dyad

\begin{tabular}{llll}
\hline Dyad & Self-triggered LREs & Other-triggered LREs & Total \\
\hline$(1)$ & 12 & 0 & 12 \\
$(2)$ & 5 & 0 & 5 \\
$(3)$ & 11 & 0 & 11 \\
$(4)$ & 0 & 1 & 1 \\
$(5)$ & 6 & 1 & 7 \\
$(6)$ & 12 & 3 & 15 \\
Total & 46 & 5 & 51 \\
\hline
\end{tabular}

The frequency of self and other-triggered LREs in the one-way task for each dyad have been presented in Table 2 and the frequency of self and other-triggered LREs in the two-way task for each dyad has been presented in Table 3.

Table 3. LREs in the two-way task in each dyad

\begin{tabular}{llll}
\hline Dyad & Self-initiated LREs & Other-initiated LREs & Total \\
\hline$(1)$ & 33 & 2 & 35 \\
$(2)$ & 28 & 7 & 35 \\
$(3)$ & 21 & 0 & 21 \\
$(4)$ & 17 & 7 & 24 \\
$(5)$ & 16 & 2 & 18 \\
$(6)$ & 18 & 7 & 25 \\
Total & 133 & 25 & 158 \\
\hline
\end{tabular}

Table 4. Modified output resulted from self- and other-initiated LREs

\begin{tabular}{llll}
\hline Task & $\begin{array}{l}\text { Modified output resulted Modified output resulted Total } \\
\text { from self }\end{array}$ & 4 & 45 \\
from other & \\
\hline One-way task & 41 & 12 & 97 \\
Two-way task & 85 & 16 & 142 \\
Total & 126 & 4 & \\
\hline
\end{tabular}

Table 4 summarizes the resulted MOs across the two tasks. In Tables 5 and 6, the frequency of LREs in the six dyads in the one-way and the two-way tasks are presented. In each task there were six dyads, each with three participants completing the task. The tables summarize the number of LREs and the results of LREs for each task. These tables have been designed based on Shehadeh 2001. 
Table 5. Comparison of the results of self-triggered and other-triggered LREs in the one-way task

\begin{tabular}{|c|c|c|c|}
\hline & \multirow{2}{*}{\begin{tabular}{|l|}
$\%$ \\
All
\end{tabular}} & \multirow{2}{*}{\begin{tabular}{|l|}
9.9 \\
5
\end{tabular}} \\
\hline & & & \\
\hline$\%$ & 90.1 & $\%$ & - \\
\hline All & 46 & Switch topic & - \\
\hline$\%$ & - & $\%$ & - \\
\hline Switch topic & - & $\begin{array}{l}\text { Insert irrelevant } \\
\text { information }\end{array}$ & t- \\
\hline$\%$ & 3.9 & $\%$ & 1.9 \\
\hline $\begin{array}{ll}\text { Repeat } & \text { trouble } \\
\text { source } & \text { without } \\
\text { modification }\end{array}$ & 2 & $\begin{array}{ll}\text { Repeat } & \text { trouble } \\
\text { source } & \text { without } \\
\text { modification }\end{array}$ & 1 \\
\hline$\%$ & - & $\%$ & - \\
\hline $\begin{array}{l}\text { Express difficulty } \\
\text { in repairing }\end{array}$ & y & \begin{tabular}{|l|} 
Express difficulty \\
in repairing
\end{tabular} & - \\
\hline$\%$ & 3.9 & $\%$ & - \\
\hline Appeal for help & 2 & Fail to repair & - \\
\hline$\%$ & 1.9 & $\%$ & - \\
\hline Fail to repair & 1 & Ignore & - \\
\hline$\%$ & 80.3 & $\%$ & 7.8 \\
\hline Modified output & 41 & Modified output & 4 \\
\hline$\%$ & 90.1 & $\%$ & 9.9 \\
\hline Self-triggered & 46 & Other-initiations & 5 \\
\hline
\end{tabular}

Table 6. Comparison of the results of self-triggered and other-triggered LREs in the two-way task

\begin{tabular}{|c|c|c|c|}
\hline & & $\%$ & 15.8 \\
\hline & & All & 25 \\
\hline$\%$ & 84.1 & $\%$ & - \\
\hline All & 133 & Switch topic & - \\
\hline$\%$ & 10.1 & $\%$ & - \\
\hline Switch topic & 16 & $\begin{array}{ll}\text { Insert } & \text { irrelevant } \\
\text { information } & \end{array}$ & $14-$ \\
\hline$\%$ & 3.7 & $\%$ & - \\
\hline $\begin{array}{l}\text { Repeat trouble source } \\
\text { without modification }\end{array}$ & e 6 & $\begin{array}{l}\text { Repeat trouble source } \\
\text { without modification }\end{array}$ & e- \\
\hline$\%$ & 1.8 & $\%$ & 1.2 \\
\hline $\begin{array}{|lll|}\text { Express difficulty in } \\
\text { repairing }\end{array}$ & $n 3$ & $\begin{array}{l}\text { Express difficulty in } \\
\text { repairing }\end{array}$ & $n 2$ \\
\hline$\%$ & 3.7 & $\%$ & .6 \\
\hline Appeal for help & 6 & Fail to repair & 1 \\
\hline$\%$ & 10.7 & $\%$ & 6.3 \\
\hline Fail to repair & 17 & Ignore & 10 \\
\hline$\%$ & 53.7 & $\%$ & 7.5 \\
\hline Modified output & 85 & Modified output & 12 \\
\hline$\%$ & 84.1 & $\%$ & 15.8 \\
\hline Self-triggered & 133 & Other-triggered & 25 \\
\hline
\end{tabular}


In Table 6, the resulted self and other-triggered LREs in the two tasks have been presented. According to Tables 5 and 6, each LRE may lead in six consequences with the source of self and seven consequences with the source of other that have been presented in the column names. In the case of other-triggered LREs, seven probable consequences are anticipatable. Out of the seven consequences, five are the same as in self-triggered including: modified output, fail to repair, express difficulty in repairing, repeat trouble source without modification, and switch topic. There are also two other consequences of other-triggered LREs: ignore, and insert irrelevant information (Based on Shehadeh, 2001).

\subsection{Analysis of the Findings}

To investigate the significance of MOs, chi-square statistic was applied to the data. The chi-square statistic formula was not applicable to the LREs resulted with the source of other in the one-way task because the number of LREs in that case was less than ten. However, chi-square was applicable to three LREs out of four in the two tasks.

The number of MOs elicited in the self-triggered manner in task one was 41 out of 46 LREs. Thus the chi-square is:

$\chi^{2}=174.58 d f=5$

The chi-square is significant for MOs resulted from self-triggered actions.

For MOs elicited in self-triggered actions in the two-way task, the number of MOs was 85 with the total number of 133 LREs. So the chi-square is:

$\chi^{2}=221.24, \mathrm{~d} f=5$

Thus, the chi-square for MO elicitation with the source of self during the two-way task is significant.

The chi-square analysis for MOs resulted with the source of other in the two-way task shows that chi-square is significant.

$\chi^{2}=43.60, \mathrm{~d} f=6$

Considering the one-way task and the two-way task used in this study, the results indicate that MOs produced as the result of self-triggered LREs are more than other possible outcomes. The chi-square statistics can be used to argue that MO production due to the learner's reaction to the output is non-random. Additionally, MOs produced in the two-way task with external request, other-triggered, the results indicate that MOs have occurred significantly more than other outcomes, and the number of MOs resulted based on other-triggered activation in the two-way task is not due to chance. However, for MOs resulted with the source of other in the one-way task, there are not enough cases to run the chi-square statistics. Therefore, it cannot be concluded that the MO production as caused by other-triggered LREs is not random. The results also indicate that modified outputs resulted based on self in each task are more than those produced based on other requests.

\section{Discussion and Conclusion}

\subsection{Interpretation of the Experiment Results}

Considering the results of this study, it can be suggested that self-triggered noticing the gap might have significant effect on EFL learners' MO elicitation in both one-way and two-way tasks. Regarding other-triggered noticing the gap in the one-way task, the results could not be used to suggest that other-triggered activation can cause MO elicitation. However, other-triggered LRE can be a source of MO production in the two-way task. Additionally, it can be argued that the occurrence of self-triggered MOs is more than other-triggered MOs both in the one-way and in the two-way tasks.

When the EFL learners used their L2 knowledge to communicate with their interlocutors, they tend to modify their interlanguage and make it more target-like. The EFL learners produced MOs even in the absence of their interlocutors' obligation to interact with them. Statistically speaking, the EFL learners performing a one-way task may go through some internal processes, considered to be some cognitive processes, which help them modify their interlanguage.

It has been found that comprehension-based programs do not lead to high levels of L2 production proficiency. Referring to one of the cases, the immersion programs in Canada can be put forward (for example you may refer to Swain, 1985; Swain and Lapkin, 1995; Lapkin and Swain, 2004). The immersion students in Canada received their lessons at school via their L2. These students had enough opportunities of receiving what Krashen (1985) called comprehensible input. However, the insufficiency of comprehensible input for L2 learning is observable in this case. Swain (1985) suggested that for the L2 learners to acquire a native-like proficiency level in their L2, 
they should have opportunities of producing L2.

MOs can be produced with the sources of self and other. However, in the case of MOs produced with the source of other in the one-way task, it seems that other-triggered LREs do not provide the EFL learners with enough opportunities for IL modification. The reason can be the lack of interlocutors' signalling non-understanding. In other words, when the EFL participants were engaged in a one-way task, they might not be willing to signal their non-understanding of the meaning to the speaker. In one-way tasks, there is no obligation for the interlocutors to share information and interact with the holder of the information to complete the task (Crookes and Gass, 1993).

Comparing the two sources of noticing a gap in the EFL learners' IL, the cases of modified output elicitation from the EFL learners in the one-way task with the source of self is significantly higher than the case of modified output elicitation from the EFL learners with the source of other. According to this function of output, it can be concluded that the L2 learners tend to test their hypotheses about their L2 when they negotiate in L2 (Swain, 1993, 1995).

In the two-way task, it was observed that the EFL learners modified their outputs with the source of self and other. In other words, it can be argued that the EFL learners participating in this study tended to notice and modify their outputs during negotiation of meaning in the two-way task with the sources of self and other. These participants modified their output while they were negotiating meaning via their L2 to complete a two-way task. These findings are in support of the previous findings in the field (for example Swain and Lapkin, 1995; Shehadeh, 1999, 2001). It can also be concluded that in a two-way task, such as the one used in this study, there is a higher chance of producing MO with internal sources than with external sources. However, one has to be careful when interpreting these types of data. Some of the observations might be attributable to sources other than internal sources or interlanguage improvement. In the following sections this idea has been elaborated on using research in other related disciplines.

\subsection{Lexical Activation in L2}

Exploring lexical and conceptual activation in L2 can help explaining some of the observed behaviour in output production. De Bot (1992) argues that L2 lexicon is added to the L1 lexicon and it results in a separate subset in the mind of the L2 learner. According to this proposal, where the meanings of the words in the two systems are the same, the two lexical entries can be saved together. However, where the meanings of the two words are different, the two lexical entries are saved separately. Growth in L2 knowledge and use leads to a systemic development, and when one of the lexical entries is activated, the system will activate the other one. According to de Bot (1992) at the low levels of L2 proficiency or in the case of learning similar entries, learning lexical entries includes the process of adding to the existing language system, i.e. L1. However, as the proficiency level increases, autonomous subsystems will appear within the person's mental lexicon (de Bot, 1992).

It can be argued that at low levels of language proficiency in L2 production, gaining mastery over a lexical entry in L2 is achieved through associating the L2 lexical entry with the L1 entry and the corresponding concept. For example, a Persian speaker has a concept for the word 'gav', meaning cow in English. When this language learner learns English as his/her L2, he/she adds the word 'cow' to his mental lexicon connected to the word 'gav' as a subset, and not necessarily to the concept. As this language learner's proficiency in L2 grows, he/she develops an autonomous subset for his/her mental lexicon in L2. Therefore, a proficient L2 speaker of English whose L1 is Persian, has two separate terms 'gav' and 'cow' in his/her mental lexicon for the concept of, or concepts of, cow.

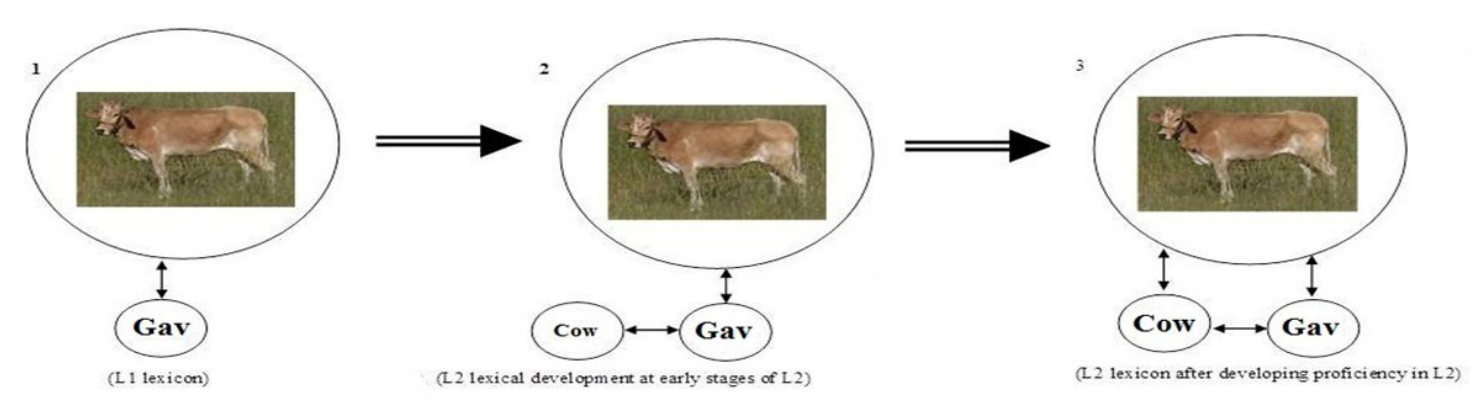

Figure 1. L2 Lexical development 
Figure 1 can be used to clarify the process of vocabulary development in L2. With respect to the argument here, we can consider two possibilities for explaining the results of output effect in L2. One is that during L2 production, at low levels of L2 proficiency, the L2 learner activates two systems simultaneously and the LREs, or some of them, are the result of appropriate form selection and may have no long-term effects on L2 production. However, if this activation contributes to growing declarative knowledge in L2, then it may be effective in L2 acquisition/learning. If there are no significant long-term effects resulted from L2 production, it has nothing, or little, to do with L2 acquisition.

\subsection{Language Production}

Most of the current language production theories consider three processes for speaking including conceptualization, formulation, and articulation (Bock and Levelt, 1994; Caplan, 1992; Meyer, 2000). In these processes, conceptualization is the generation of a message related to the speaker's communicative intention. Conceptualization is a prelinguistic phase of language production that specifies the content of the utterance. The generated message acts as the formulation input. During formulation, appropriate entries in the mental lexicon of the speaker are available and the syntactic and morpho-phonological structures of the utterance are constructed. This is followed by the articulatory processes being activated and used based on the produced information (Meyer, 2000). Two major steps of lexical selection and word-form encoding are considered to be at work in the process of lexical access to content words (Meyer, 2000). Lexical access takes place during syntactic encoding that one or more lemmas from the mental lexicon is/are activated by the partial use of the message. In some of the psycholinguistic views, the syntactic properties of a lexical entry are represented in the lemma (Meyer, 2000).

\subsection{The Standard Model}

Before selection of the articulatory commands for an utterance, according to the standard model, the stored form representations are decoded into some abstract phonological representations. The "segmental tier" and the "metrical tier" are the two independent results of decompositioning the phonological representation (Meyer, 2000 , p. 57). The reason that the motor programs are not directly retrieved for entire morphemes is that any morpheme can be produced, or pronounced, in many different but systematically related ways. Based on these facts, Meyer (2000) argues that allowance of different pronunciations of a single morpheme in word-generations must meet two prerequisites: 1) the stored lexical representation for the morpheme should be abstract enough to permit different realizations of the morpheme, 2) during the word-form encoding process the internal structure of the morpheme should become visible to the processor and accessible for modification (for example Spencer, 1991). Meyer (2000) suggests that the decomposition process of morphemes into two constituents of segmental and metrical can be regarded as one way of making the phonological structure of the morphemes visible and modifiable to the processor. It has been argued that during language production, the language producer relies on many different aspects of his/her stored language knowledge about words including the words meaning, syntactic properties of the words, their morphological composition, and sound structures of them. The information about the words is retrieved from the memory during lexical access process to map a lexical concept to its appropriate articulatory program. It has also been argued that this lexical access process includes two major steps namely lemma retrieval and word-form encoding (for elaborate discussion see Levelt, 1989; Roelofs, 2000). In lemma retrieval, a lemma is activated from memory by the use of a lemma lexical concept, making syntactic properties of the word available for syntactic encoding processes (Roelofs, 2000; see also Kempen \& Hoenkamp, 1987). In order to construct a phonetic plan, a lemma and its parameter values should be used in recovering the appropriate morpho-phonological properties from memory. Lexical access may be initiated by a message or by a perceived spoken or written word. But in WEAVER ++ model, it is assumed that a perceived word activates lemmas and word-forms in parallel (Roelofs, 2000). In the following paragraphs, these data will be used for explaining what might be happening in L2 output production. Please note that these were just few cases of using other related fields to have a clearer picture of the process at work in language production.

The $\mathrm{L} 2$ learner can notice the form in the incoming data, i.e. input, when he/she does not need to fully use his/her short-term memory capacity to extract meaning from the input. In other words, till the time that the L2 learner has not automatized parts of his/her L2 knowledge, he/she has to rely on his/her short-term memory capacity to extract meaning and cannot notice the new form(s) and acquisition/learning of the new form(s) may not occur. Furthermore, the existence and the quality of any automatization related to output production in L2 need to be investigated. According to Nobuyoshi and Ellis (1993) one of the definitions of acquisition is through gaining more control over the already internalized forms, and according to Swain and Lapkin, producing output in L2 can increase gaining control over the L2 forms. It can be concluded that producing output helps the L2 learner automatize some parts of his/her L2 knowledge. The result can be freeing some of the learner's short-term 
memory space. This; with respect to the discussion on short-term memory, long-term memory, controlled, and automatic processing (Towell \& Hawkins, 1994); can help the learner notice the new form in the input and acquisition/learning may take place.

Consequently, one has to note that some of the cases that can be recorded as self-triggered, or self-initiation, can be just the representations of the processes involved in lexical activation in L2, in which the L2 learner tries to choose from two words/forms representing one notion (part 2 in Figure 1). Other cases, both with the source of self and other, can be interpreted by understanding the devotion of short-term memory capacity to concept related information, at first, followed by the language related item(s), when the short-term memory has the capacity to do so. In any case, the L2 form has already been learnt, and the observation might be attributable to the learnt knowledge activation.

However, one of the functions of output production in L2 can be practice function through which the L2 knowledge will eventually become automated. By automatization of some aspects of the L2, short-term memory will have fewer loads and would have space for the syntactic knowledge to be activated and applied to the L2.

Looking back at the history of research into the output hypothesis, it can be inferred that most of the research studies done in the field have been on occurrences of the comprehensible output per se. Also, in such studies there has been less attention on the effect of task, i.e. task type, on modified output elicitation from L2 learners (for exceptions, see Shehadeh, 1999, 2001; Shekary, 2004). It should be noted here that in the present study, the intention was to investigate the effects of task type, one-way and two-way tasks, on modified output elicitation from EFL learners in NNS-NNS interactions. In other words, considering all the potential influences these two task types may have on interaction, it was intended to explore the possibility of modified output production by the EFL learners. It was observed that in interactions between the EFL learners, most of the repairs were with the source of self. Moreover, more cases of MO were observed in the two-way task. This could be attributable to the nature, length, and the situation of the task as well as the task type.

However, as it was discussed earlier, the modifications in the output might mainly be attributable to mental competitions between lexemes in the mind of the language learner, or semantic-syntactic initiation preference by the short-term memory. One might even argue that such a competition can also exist at the grammatical level as well. However, further investigations can help to have a better understanding of this point. Additionally, longitudinal studies are required to shed light on the acquisition effect(s) of the output and MO. In addition to recognizing the role of comprehensible input in L2 acquisition process, Ellis (2005) also emphasizes the role of output in L2 instruction and mentions "successful instructed language learning also requires opportunities for output" (p. 9). Even if the sole contribution of producing output in L2 be automatization of some of the L2 forms, it still can contribute to language acquisition by giving the learner the chance of considering and applying some of the already learnt L2 rules to the conversation that would not have a chance to be activated if some of the forms have not been automatized. Then, output would fall in the second category of acquisition based on Nobuyoshi and Ellis (1993), which is gaining more control over the learnt L2 forms.

\section{Limitations of the Study}

The present research was conducted using EFL learner participants at intermediate level, which might limit the generalizations of the findings. To ensure the generalizability power of the findings, participants at other proficiency levels can be used in the future research. Another shortcoming might be the use of just L2 learners of English. Research in learning other second languages can help in increasing our understanding of the role of output in SLA. Additionally, increasing the number of participants would help in making stronger conclusions. Finally, studying the longitudinal effects of L2 production can acknowledge us better of the long-term acquisition roles output might have.

\section{Acknowledgements}

First and foremost, I need to thank the participants who volunteered their time for the sake of research and scientific development. Two knowledgeable professors at the University of Isfahan, Dr Akbar Afghari and Dr Zohreh Kasaian, helped me by giving constructive feedback on the initial drafts. Kathy Block, writing coordinator in Academic Learning Centre at the University of Manitoba, provided useful comments on the final drafts of the manuscript. To me, she is very successful in helping people reach their own way of thinking. I need to thank the anonymous reviewers with the English Language Teaching Journal who provided useful comments. Every remaining mistake is mine. 


\section{References}

Afitska, O. (2012). Role of focus-on-form instruction, corrective feedback and uptake in second language classrooms: Some insights from recent second language acquisition research. The Language Learning Journal. http://dx.doi.org/10.1080/09571736.2012.701320

Anderson, J. R. (1982). Acquisition of cognitive skill. Psychological review, 89(4), 369. http://dx.doi.org/10.1037/0033-295X.89.4.369

Baddeley, A. D. (2002). Is working memory still working? European psychologist, 7(2), 85-97. http://dx.doi.org/10.1027//1016-9040.7.2.85

Bock, J. K., \& Griffin, Z. M. (2000). Producing words: How mind meets mouth. In L. Wheeldon (Ed.), Aspects of language production (pp. 7-47). Sussex: Psychology Press.

Bock, J. K., \& Levelt, W. J. M. (1994). Language production: Grammatical encoding. In M. A. Gernsbacher (Ed.), Handbook of psycholinguistics (pp. 945-984). San Diego: Academic Press.

Brown, S. (2006). Teaching listening. New York: Cambridge University Press.

Bygate, M. (2001). Effects of task repetition on the structure and control of oral language. In Bygate, Skehan, \& Swain (Eds.), Researching pedagogic tasks: Second language learning, teaching, and testing (pp. 21-48). Harlow: Pearson education.

Caplan, D. (1992). Language: Structure, processing, and disorders. Cambridge: MIT Press.

Clark, E. (1982). Language change during language acquisition. In M. Lamb, \& A. Brown (Eds.), Advances in child development (pp. 171-197). Hillsdale, NJ: Erlbaum.

Crookes, G., \& Gass, S. (Eds.) (1993). Tasks and language learning: Integrating theory and practice. Clevedon: Multilingual Matters.

Cumming, A. (1990). Metalinguistic and ideational thinking in second language composing. Written Communication, 7, 482-511. http://dx.doi.org/10.1177/0741088390007004003

De Bot, K. (1992). A bilingual production model: Levelt's speaking model adapted. Applied Linguistics, 13, 1-24. http://dx.doi.org/10.1093/applin/13.1.1

De Bot, K. (1996). The psycholinguistics of the output hypothesis. Language learning, 46(3), 529-555. http://dx.doi.org/10.1111/j.1467-1770.1996.tb01246.x

De Bot, K., Paribakht, T., \& Wesche, M. (1997). Toward a lexical processing model of second language vocabulary acquisition: Evidence from ESL reading. Studies in Second Language Acquisition, 19, 309-406. http://dx.doi.org.proxy1.lib.umanitoba.ca

Dörnyei, Z., \& Kormos, J. (1998). Problem-solving mechanisms in L2 communication: A psycholinguistic perspective. Studies in Second Language Acquisition, 20, 349-385. http://dx.doi.org.proxy1.lib.umanitoba.ca/

Ellis, R. (1994). The study of second language acquisition. Oxford: Oxford University Press.

Ellis, R. (2005). Principles of instructed language learning. System, 33(2), 209-224. http://dx.doi.org/10.1016/j.system.2004.12.006

Foster, P. (1998). A classroom perspective on the negotiation of meaning. Applied linguistics, 19(1), 1-23. http://dx.doi.org/10.1093/applin/19.1.1

Gass, S. (1997). Input, interaction and second language learner. New Jersey: Lawrence Erlbum, Mahwah.

Hill, L. A. (1980). Steps to understanding. Oxford University Press.

Izumi, S., Bigelow, M., Fujiwara, M., \& Fearnow, S. (1999). Testing the output hypothesis. Studies in Second Language Acquisition, 21(3), 421-452.

Izumi, S., \& Bigelow, M. (2000). Does Output Promote Noticing and Second Language Acquisition? Tesol Quarterly, 34(2), 239-278. http://dx.doi.org/10.2307/3587952

Izumi, S. (2002). Output, input enhancement, and the noticing hypothesis. SSLA, 24, 541-577. http://dx.doi.org/10.1017.S0272263102004023

Izumi, S. (2003). Comprehension and production processes in second language learning: In search of the psycholinguistic rationale of the output hypothesis. Applied Linguistics, 24(2), 168-196. 
http://dx.doi.org/10.1093/applin/24.2.168

Kempen, G., \& Hoenkamp, E. (1987). An incremental procedural grammar for sentence formulation. Cognitive science, 11(2), 201-258. http://dx.doi.org/10.1016/S0364-0213(87)80006-X

Kormos, J. (1999). Monitoring and Self-Repair in L2. Language learning, 49(2), $303-342$. http://dx.doi.org/10.1111/0023-8333.00090

Kormos, J. (2000). The timing of self-repairs in second language speech production. Studies in Second Language Acquisition, 22(2), 145-167.

Kowal, M., \& Swain, M. (1994). Using collaborative language production tasks to promote students' language awareness 1. Language Awareness, 3(2), 73-93. http://dx.doi.org/10.1080/09658416.1994.9959845

Kowal, M., \& Swain, M. (1997). From semantic to syntactic processing: How can we promote in it in the immersion classroom? In R. K. Johnson, \& M. Swain (Eds.), Immersion education: International perspectives (pp. 284-309). Cambridge: Cambridge University Press.

Krashen, S. (1985). The input hypothesis: Issues and implications. London: Longman.

Lapkin, S., \& Swain, M. (2004). What underlies immersion students' production: The case of avoir besoin de. Foreign Language Annals, 37(3), 349-355. http://dx.doi.org/10.1111/j.1944-9720.2004.tb02693.x

Levelt, W. J. M. (1989). Speaking: From intention to articulation. Cambridge. MA: The MIT Press.

Long, M. (1991). Focus on form: A design feature in language teaching methodology. In K. De Bot, R. Ginsberg, \& C. Kramsch (Eds.), Foreign language research in cross-cultural perspective (pp. 39-52). Philadelphia: John Benjamins.

Long, M. (1996). The role of the linguistic environment in second language acquisition. In W. Ritchie, \& T. K. Bhatia (Eds.), Handbook of second language acquisition (pp. 413-468). Orlando: Academic Press.

Lyster, R. (1998). Negotiation of form, recasts, and explicit correction in relation to error types and learner repair in immersion classrooms. Language learning, 48(2), 183-218. http://dx.doi.org/10.1111/1467-9922.00039

McLaughlin, B. (1987). Theories of second language learning. London: Edward Arnold.

Meyer, A. S. (2000). Form representations in word production. In L. Wheeldon (Ed.), Aspects of language production (pp. 49-70). Sussex: Psychology Press.

Monsell, S. (1987). On the relation between lexical input and output pathways for speech. In A. Allport, D. G. Mackay, W. Prinz, \& E. Scheerer (Eds.), Language perception and production: Relationship between listening, speaking, and writing (pp. 273-311). London: Academic Press.

Nickels, L., \& Howards, D. (2000). When the words won't come: Relating of impairments and models of spoken word production. In L. Wheeldon (Ed.), Aspects of language production (pp. 115-142). Sussex: Psychology Press.

Nobuyoshi, J., \& Ellis, R. (1993). Focused communication tasks and second language acquisition. ELT journal, 47(3), 203-210. http://dx.doi.org/10.1093/elt/47.3.203

Pica, T., Holliday, L., Lewis, N., \& Morgenthaler, L. (1989). Comprehensible output as an outcome of linguistic demands on the learner. Studies in second language acquisition, 11(1), 63-90. http://dx.doi.org/10.1017/S027226310000783X

Pica, T. (1994). Research on Negotiation: What Does It Reveal About Second-Language Learning Conditions, Processes, and Outcomes? Language learning, 44(3), 493-527. http://dx.doi.org/10.1111/j.1467-1770.1994.tb01115.x

Roelofs, A. (2000). WEAVER++ and other computational models of lemma retrieval and word-form encoding. In Wheeldon, L. (Ed.), Aspects of language production (pp. 71-114). Sussex: Psychology Press.

Shehadeh, A. (1999). Non-Native Speakers' Production of Modified Comprehensible Output and Second Language Learning. Language learning, 49(4), 627-675. http://dx.doi.org/10.1111/0023-8333.00104

Shehadeh, A. (2001). Self-and Other-Initiated Modified Output during Task-Based Interaction. TESOL Quarterly, 35(3), 433-457. http://dx.doi.org/10.2307/3588030

Shehadeh, A. (2002). Comprehensible output, from occurrence to acquisition: An agenda for acquisitional research. Language Learning, 52(3), 597-647. http://dx.doi.org/10.1111/1467-9922.00196

Shekary, M. (2004). Negotiation of meaning and noticing in cyberspace: The role of text-based on-line chat in 
the development of SLA (Unpublished MA thesis). University of Isfahan, Isfahan, Iran.

Shiffrin, R. M., \& Shchneither, W. (1977). Controlled and automatic human information processing. II: Perceptual learning, automatic, attending, and a general theory. Psychological Review, 84, 127-190.

Spencer, A. (1991). Morphological theory: An introduction to word structure in generative grammar. Cambridge: Blackwell.

Swain, M. (1985). Communicative competence: Some roles of comprehensible and comprehensible output in its development. In Gass, S., \& Madden, C. (Eds.), Input in Second Language Acquisition (pp. 235-256). New York: Newbury House.

Swain, M. (1991). French immersion and its offshoots: Getting two for one. In B. F. Freed (Ed.), Foreign language acquisition research and the classroom (pp. 91-103). Lexington, MA: D. C. Heath.

Swain, M. (1993). The Output Hypothesis: Just Speaking and Writing Aren't Enough. Canadian Modern Language Review, 50(1), 158-164.

Swain, M. (1995). Three functions of output in second language learning. In G. Cook, \& B. Seidhofer (Eds.), Principles and practice in applied linguistics (pp. 125-144). Oxford: Oxford University Press.

Swain, M., \& Lapkin, S. (1995). Problems in output and the cognitive processes they generate: A step towards second language learning. Applied Linguistics, 16(3), 371-391. Retrieved from $\mathrm{http}: / /$ search.proquest.com/docview/54849980?accountid=14569

Swain, M. (1997). Collaborative dialogue: Its contribution to second language learning. Revisita Canaria de Estudios Ingleses, 34, 115-132.

Swain, M. (1998). Focus on form through conscious reflection. In C. Doughty, \& J. Williams (Eds.), Focus on form in classroom second language acquisition (pp. 64-81). Cambridge: Cambridge University Press.

Swain, M. (2000). The output hypothesis and beyond: Meditating acquisition through collaborative dialogue. In C. Lantolf (Ed.), Sociocultural theory and second language learning (pp. 97-114). Oxford: Oxford University Press.

Towell, R., \& Hawkins, R. (1994). Approaches to second language acquisition. Bristol: Multilingual Matters Ltd.

Van den Branden, K. (1997). Effects of negotiation on language learners' output. Language Learning, 47(4), 589-636. http://dx.doi.org/10.1111/0023-8333.00023

White, L. (1991). Adverb placement in second language acquisition: Some effects of positive and negative evidence in the classroom. Second Language Research, 7, 133-161. http://dx.doi.org/10.1177/026765839100700205

\section{Copyrights}

Copyright for this article is retained by the author(s), with first publication rights granted to the journal.

This is an open-access article distributed under the terms and conditions of the Creative Commons Attribution license (http://creativecommons.org/licenses/by/3.0/). 